\title{
Effects of meal consumption on whole body leucine and alanine kinetics in young adult men
}

\author{
BY LEONARD J. HOFFER ${ }^{1 *}$, RUSSELL D. YANG ${ }^{1}$, \\ DWIGHT E. MATTHEWS ${ }^{2}$, BRUCE R. BISTRIAN ${ }^{3}$, DENNIS M. BIER ${ }^{2}$ \\ AND VERNON R. YOUNG ${ }^{1} \dagger$ \\ ${ }^{1}$ Laboratory of Human Nutrition and Clinical Research Center, Department of Nutrition \\ and Food Science, Massachusetts Institute of Technology, Cambridge, \\ Massachusetts 02139, USA \\ ${ }^{2}$ Departments of Medicine and Pediatrics, Washington University School of Medicine, \\ St Louis, Missouri 63110, USA \\ ${ }^{3}$ The Cancer Research Institute, New England Deaconess Hospital, Boston, \\ Massachusetts 02215, USA
}

\section{(Received 3 April 1984 - Accepted 6 August 1984)}

1. The effects of meal consumption on plasma leucine and alanine kinetics were studied using a simultaneous, primed, continuous infusion of $L-\left[1-{ }^{13} \mathrm{C}\right]$ leucine and $L-\left[3,3,3-{ }^{2} \mathrm{H}_{3}\right]$ alanine in four healthy, young, adult male subjects. The study included an evaluation of the effect of sampling site on plasma amino acid kinetics, with blood being drawn simultaneously from an antecubital and dorsal heated hand vein.

2. In comparison with the postabsorptive state, the ingestion of small hourly meals resulted in a $35 \%$ increase in plasma leucine flux and a $77 \%$ increase in leucine oxidation. Calculated entry of leucine into the plasma compartment from endogenous sources decreased by $65 \%$. Plasma alanine flux more than doubled, indicating a significant enhancement in de novo alanine synthesis. ${ }^{13} \mathrm{C}$ enrichment of leucine in venous and arterialized plasma did not differ significantly, but alanine flux calculated from isotopic measurement in venous plasma was substantially greater than that based on analysis of arterialized blood plasma.

Recent tracer studies have permitted a description of the response of whole-body amino acid metabolism to meal ingestion in adult subjects. Garlick and co-workers (Garlick et al. 1980; Clugston \& Garlick, 1982) administered L- $\left[1-{ }^{14} \mathrm{C}\right]$ leucine by continuous intravenous infusion over a $24 \mathrm{~h}$ period with small hourly meals being given to test subjects during the day and with food being withheld at night. In a study carried out earlier in our laboratories, different groups of young adult men were studied in the postabsorptive overnight (fasted) or fed states using primed intravenous infusions of L- $\left[1{ }^{13} \mathrm{C}\right]$ leucine (Motil et al. 1981 $a, b$ ). More recently, Rennie et al. (1982) have published a study using a similar design. Although a stimulation in plasma leucine flux and oxidation was generally observed when meals were given (Garlick et al. 1980; Motil et al. $1981 a$, b; Clugston \& Garlick, 1982; Rennie et al. 1982), different conclusions were reached concerning the responses of leucine incorporation into and liberation from whole-body proteins in association with meal ingestion. Consequently, we have undertaken a study in which whole-body leucine kinetics were studied in the same individual during the postabsorptive state in the morning, then again following consumption of small hourly meals later in the day. The present results permit some resolution of the differences observed in the earlier studies concerning the effects of feeding on whole-body leucine metabolism. In addition, we have explored the metabolism of the nutritionally-dispensable (non-essential) amino acid, alanine, in relation to meal feeding, and examined the possible consequences of using different plasma sampling sites on the determination of amino acid flux.

\footnotetext{
* Present address: McGill University Nutrition and Food Science Centre, Royal Victoria Hospital, Montreal, Quebec H3A 1A1, Canada.

$\dagger$ For reprints.
} 


\section{MATERIALS AND METHODS}

\section{Subjects}

Four young, adult male Massachusetts Institute of Technology (MIT) students, determined to be in good health on the basis of medical history, physical examination and routine biochemical blood plasma measurements, were studied at the MIT Clinical Research Center (CRC). Each subject gave his written consent for the protocol, approved by the MIT Committee on the Use of Humans as Experimental Subjects and the CRC Policy and Executive Committees. They were paid for their participation in the study.

\section{Diets and study design}

The subjects were given, for $4 \mathrm{~d}$, an adequate diet (16\% of energy from protein, $44 \%$ from carbohydrate and $40 \%$ from fat) providing $1.5 \mathrm{~g}$ protein $/ \mathrm{kg}$ body-weight (BW) per $\mathrm{d}$ and a maintenance energy intake, as determined by diet history. All meals were taken in the CRC dining room. On the fifth morning and after a $14 \mathrm{~h}$ fast, baseline blood and expired-air samples were taken and a $10 \mathrm{~h}$ isotope-infusion study was begun. After $4 \mathrm{~h}$, small hourly meals were consumed for the following $6 \mathrm{~h}$, providing a total of $0.75 \mathrm{~g}$ protein $/ \mathrm{kg} \mathrm{BW}$ and $92 \mathrm{~kJ}(22 \mathrm{kcal}) / \mathrm{kg} \mathrm{BW}$. The meals consisted of drinks and cookies composed of whole egg and glucose polymer (Polycose; Ross Laboratories), including supplements of calcium phosphate, potassium phosphate and sodium chloride. The leucine and alanine contents of the whole-egg protein were taken to be 86 and $57 \mathrm{mg} / \mathrm{g}$ respectively (FAO, 1970). The meals were designed to provide, in total, half the daily protein and energy intake and consisted of (in terms of energy) $14 \%$ protein, $52 \%$ carbohydrate and $34 \%$ fat.

\section{Materials}

$\mathrm{L}-\left[1-{ }^{13} \mathrm{C}\right]$ leucine $\left(90 \%{ }^{13} \mathrm{C}\right), \mathrm{L}-\left[3,3,3-{ }^{2} \mathrm{H}_{3}\right]$ alanine $\left(98 \%\right.$ enriched) and $\left[{ }^{13} \mathrm{C}\right] \mathrm{NaHCO} \mathrm{HCO}_{3}(90 \%$ ${ }^{13} \mathrm{C}$ ) were obtained from KOR Isotopes, Cambridge, MA. Stock solutions of the isotopes were prepared by aseptic technique using sterile saline $(9 \mathrm{~g} \mathrm{NaCl} / 1)$ solution and then accurately diluted with sterile saline solution before use in the infusion study. All solutions were tested for sterility and absence of pyrogens by standard laboratory procedures.

\section{Isotope infusion protocol}

Each subject fasted for $14 \mathrm{~h}$ before the study and the fast was continued during the initial $4 \mathrm{~h}$ of the isotope-infusion period. Following sampling of blood and expired air for baseline measurements, the tracers were administered through an intravenous catheter placed in an antecubital vein. The rate of infusion was controlled by a calibrated syringe pump (Model 940; Harvard Apparatus Inc., Millis, MA). Blood was sampled both from an antecubital vein in the contralateral arm and also from an ipsilateral dorsal heated hand vein to provide arterialized blood (Abumrad et al. 1981). Venous and arterialized blood samples were drawn simultaneously. The leucine tracer was infused at a constant rate of 10 or $15 \mu \mathrm{g} / \mathrm{kg} \mathrm{BW}$ per min, preceded by a priming dose of 600 or $900 \mu \mathrm{g} / \mathrm{kg} \mathrm{BW}$. The greater infusion rate and priming dose were chosen in two subjects (nos. 02 and 04) because of concern that plateau isotopic enrichments during the fed state might be too low to determine accurately at the lesser rate; subsequently either rate was found to be satisfactory. The body bicarbonate pool was primed by a bolus injection of $\left[{ }^{13} \mathrm{C}\right] \mathrm{NaHCO}_{3}(75 \mu \mathrm{g} / \mathrm{kg} \mathrm{BW})$. The alanine tracer was given at a rate of $14 \mu \mathrm{g} / \mathrm{kg} \mathrm{BW}$ per min with no priming dose. The leucine and alanine tracer solutions were infused via a calibrated syringe pump at the rate of $0 \cdot 1394 \mathrm{ml} / \mathrm{min}$.

Blood samples were drawn into heparinized tubes, immediately placed on ice and the plasma separated and stored frozen for subsequent analysis. During the fourth hour, blood samples were obtained at 15 -min intervals and expired air samples at 12 -min intervals to 
define isotopic plateau in plasma amino acids and expired carbon dioxide. At the beginning of the fifth hour, immediately after the blood and air samples were obtained, small hourly meals were given for the following $6 \mathrm{~h}$ (see Fig. 1, p. 34). During the tenth hour (following the sixth meal), blood and air samples were taken to determine the plateau of enrichment in plasma leucine and expired air. Minute ventilation rates were determined, as described previously (Matthews et al. 1980). Fourteen to sixteen measurements were taken for each subject throughout the study period. Rates of oxygen consumption required approximately $2 \mathrm{~h}$ to stabilize when meal eating was begun, and values obtained during this time were not used.

Samples of expired air collected in anaesthesia bags were bubbled through $0.1 \mathrm{M}$-sodium hydroxide to trap carbon dioxide for subsequent determination of ${ }^{13} \mathrm{CO}_{2}$ enrichment, again as described elsewhere (Matthews et al. 1980; Motil et al. $1981 \mathrm{~b}$ ). ${ }^{13} \mathrm{C}$ enrichment of expired $\mathrm{CO}_{2}$ taken during both postabsorptive and fed states were corrected for previous baseline enrichments. For the fed state, baseline enrichment due to the food was determined in a control experiment in which meals were given but without tracer. During the $10 \mathrm{~h}$ study, the subjects remained in bed in a quiet, temperature-controlled room.

\section{Analytical methods}

Plasma free amino acid levels and infusate amino acid concentrations were measured with an amino acid analyser (Model 121C; Beckman Instruments, Palo Alto, CA). Free amino acids were isolated from $200 \mu \mathrm{l}$ plasma from which were derived the $N$-acetyl $n$-propyl (NAP) esters for measurement of plasma $\left[1-{ }^{13} \mathrm{C}\right]$ leucine and $\left[3,3,3-{ }^{2} \mathrm{H}_{3}\right]$ alanine enrichment. NAP-leucine and NAP-alanine could be separated chromatographically from the other NAP-amino acids using techniques described elsewhere (Matthews et al. 1979, 1980). $\left[1-{ }^{13} \mathrm{C}\right]$ leucine and $\left[3,3,3-{ }^{2} \mathrm{H}_{3}\right]$ alanine enrichments were measured by methane chemical ionization-gas chromatography-mass spectroscopy and selected ion-monitoring of the $[\mathrm{MH}]+$ and $[\mathrm{MH}+1]+$ or $[\mathrm{MH}+3]+$ ions $(\mathrm{m} / \mathrm{z} 216$ and 217 for leucine, 174 and 177 for alanine), also as previously described (Matthews et al. 1979, 1980). The ${ }^{13} \mathrm{CO}_{2}$ enrichment of expired air samples was determined by isotope-ratio mass spectrometry following regeneration by mixing the $\mathrm{NaOH}$-expired air solution with concentrated phosphoric acid (Matthews et al. 1980).

\section{Calculations and evaluation of results}

Leucine and alanine fluxes $(\mu \mathrm{mol} / \mathrm{kg} \mathrm{BW}$ per $\mathrm{h})$ were calculated by conventional tracerdilution expressions from plasma free $\left[1-{ }^{13} \mathrm{C}\right]$ leucine and $\left[3,3,3-{ }^{2} \mathrm{H}_{3}\right]$ alanine enrichments during the period of isotopic steady-state. The latter was achieved within approximately 4-5 $\mathrm{h}$ after the start of meal eating. Rates of leucine oxidation, based on measurement of the $\mathrm{CO}_{2}$ production rate and ${ }^{13} \mathrm{CO}_{2}$ enrichment, were determined as previously described (Matthews et al. 1980). The rate of leucine release from endogenous protein breakdown was taken as the difference between leucine flux and dietary intake; uptake of leucine from plasma for incorporation into body proteins was estimated from the difference between leucine flux and oxidation. This model has been employed by others (e.g. Waterlow et al. 1978; Garlick et al. 1980), and ourselves (Motil et al. 1981 a, b), for the analysis of plasma amino acid kinetics.

Statistical analysis of the results was by means of the paired $t$ test.

\section{RESULTS AND DISCUSSION}

Table 1 shows the subject characteristics and the values for gas exchange before and during meal eating. The rate of $\mathrm{O}_{2}$ consumption increased $(P<0.01)$ when meal ingestion began with re-establishment of a steady level within $2 \mathrm{~h}$ of beginning food consumption. 
Table 1. Subject characteristics and their respiratory carbon dioxide and oxygen exchanges following meal consumption

(Mean values with their standard errors)

\begin{tabular}{|c|c|c|c|c|c|c|c|c|c|c|}
\hline \multirow{3}{*}{$\begin{array}{l}\text { Subject } \\
\text { no. }\end{array}$} & \multirow{3}{*}{$\begin{array}{c}\text { Age } \\
\text { (years) }\end{array}$} & \multirow{3}{*}{$\begin{array}{l}\text { Body-wt } \\
(\mathrm{kg})\end{array}$} & \multicolumn{4}{|c|}{ Postabsorptive state } & \multicolumn{4}{|c|}{ Fed state } \\
\hline & & & \multicolumn{2}{|c|}{$\begin{array}{l}\mathrm{O}_{2} \text { consumption } \\
(\mathrm{ml} / \mathrm{min})\end{array}$} & \multicolumn{2}{|c|}{$\begin{array}{l}\mathrm{CO}_{2} \text { production } \\
(\mathrm{ml} / \mathrm{min})\end{array}$} & \multicolumn{2}{|c|}{$\begin{array}{c}\mathrm{O}_{2} \text { consumption } \\
(\mathrm{ml} / \mathrm{min})\end{array}$} & \multicolumn{2}{|c|}{$\begin{array}{c}\mathrm{CO}_{2} \text { production } \\
(\mathrm{ml} / \mathrm{min})\end{array}$} \\
\hline & & & Mean & $\mathbf{S E}$ & Mean & $\mathbf{S E}$ & Mean & SE & Mean & SE \\
\hline 01 & 22 & $64 \cdot 6$ & 210 & 7 & 181 & 3 & 274 & 6 & 228 & 5 \\
\hline 02 & 22 & $75 \cdot 0$ & 216 & 7 & 171 & 5 & 254 & 6 & 208 & 8 \\
\hline 03 & 26 & $65 \cdot 2$ & 212 & 2 & 171 & 3 & 248 & 1 & 226 & 1 \\
\hline 04 & 25 & $84 \cdot 0$ & 198 & 8 & 169 & 10 & 252 & 6 & 206 & 5 \\
\hline Mean & 24 & $72 \cdot 2$ & 209 & & 173 & & 257 & & 217 & \\
\hline $\mathrm{SE}$ & 1 & $4 \cdot 6$ & 4 & & 3 & & 5 & & 6 & \\
\hline
\end{tabular}

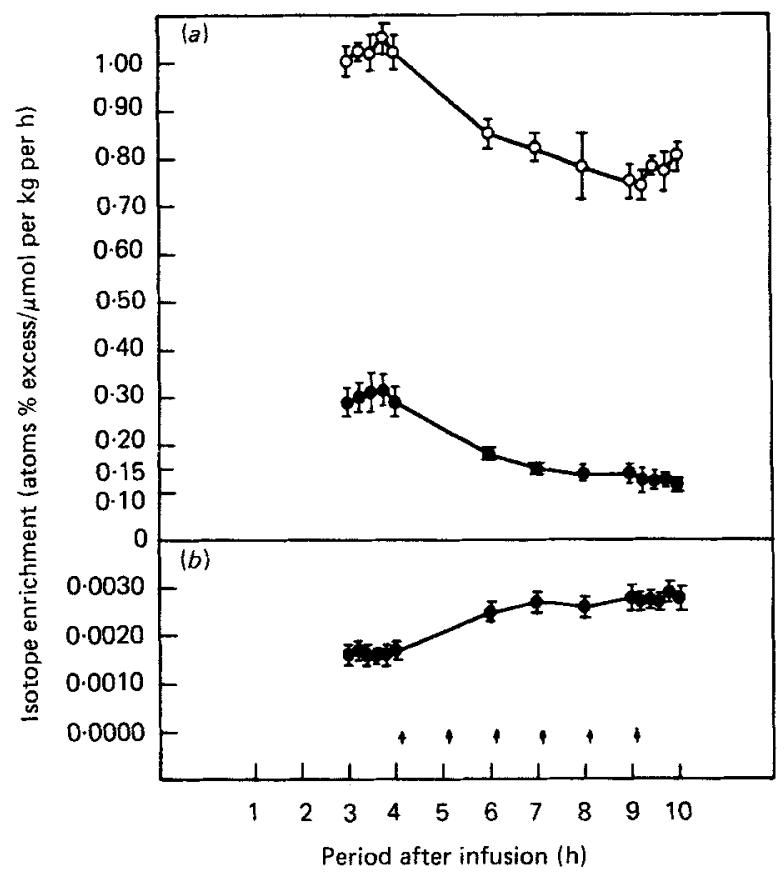

Fig. 1. (a) Arterialized plasma enrichments of $\left[1-{ }^{12} \mathrm{C}\right]$ leucine $(\mathrm{O})$ and $\left[3,3,3-{ }^{2} \mathrm{H}_{3}\right]$ alanine $(\mathrm{O})$ adjusted to an isotope infusion rate of $1 \mu \mathrm{mol} / \mathrm{kg}$ per $\mathrm{h}$. (b) Expired air enrichment of ${ }^{13} \mathrm{CO}_{2}$ adjusted to a [1-13 $\left.\mathrm{C}\right]$ leucine infusion rate of $1 \mu \mathrm{mol} / \mathrm{kg}$ per h. Meals ( $\uparrow$ ) were fed from hours 4 to 9 . Values are expressed as mean values with their standard errors represented by vertical bars.

Postabsorptive venous plasma leucine and alanine concentrations (mean with SE) were 143 (SE 4) and 251 (SE 19) $\mu \mathrm{M}$ respectively. During the sixth hour of meal eating, leucine and alanine concentrations were 184 (SE 10) and 497 (SE 12) $\mu \mathrm{M}$ respectively.

Steady-state plasma $\left[1-{ }^{13} \mathrm{C}\right]$ leucine, $\left[3,3,3-{ }^{2} \mathrm{H}_{3}\right]$ alanine and expired-air ${ }^{13} \mathrm{CO}_{2}$ enrichments were achieved during the postabsorptive period and then again during the period of meal eating. These values are depicted in Fig. 1.

During meal consumption, plasma leucine flux was $35 \%$ higher and leucine oxidation 
Table 2. Plasma leucine kinetics in young men during the postabsorptive and fed states

\begin{tabular}{|c|c|c|c|c|c|c|c|c|c|}
\hline \multirow{2}{*}{$\begin{array}{c}\text { Subject } \\
\text { no. }\end{array}$} & \multicolumn{4}{|c|}{ Postabsorptive state } & \multicolumn{5}{|c|}{ Fed state } \\
\hline & Fluxt & Oxidation & Removal $\ddagger$ & Entry§ & Intake & Flux $\uparrow$ & Oxidation & Removal + & Entry§ \\
\hline 01 & 85.6 & $10-8$ & $74 \cdot 8$ & 85.6 & $82 \cdot 4$ & $122 \cdot 3$ & $19 \cdot 4$ & 102.9 & 39.9 \\
\hline 02 & $84 \cdot 1$ & $15 \cdot 6$ & $68 \cdot 5$ & $84 \cdot 1$ & 84.8 & $110 \cdot 8$ & $23 \cdot 3$ & $87 \cdot 5$ & $26 \cdot 0$ \\
\hline 03 & 83.8 & 13.6 & $70 \cdot 2$ & 83.8 & 78.6 & 104.6 & $24 \cdot 6$ & 80.0 & $26 \cdot 0$ \\
\hline 04 & $76 \cdot 1$ & $11 \cdot 3$ & $64 \cdot 8$ & $76 \cdot 1$ & 80.8 & 105.9 & $23 \cdot 4$ & 82.5 & $25 \cdot 1$ \\
\hline Mean & $82 \cdot 4$ & $12 \cdot 8$ & 69.6 & 82.4 & $81 \cdot 6$ & $110^{\cdot 9^{*}}$ & $22 \cdot 7^{*}$ & $88 \cdot 2^{*}$ & $29 \cdot 2^{* *}$ \\
\hline $\mathrm{SE}$ & $2 \cdot 2$ & $1 \cdot 1$ & $2 \cdot 0$ & $2 \cdot 2$ & 1.3 & 4.0 & 1.2 & $5 \cdot 1$ & 3.6 \\
\hline
\end{tabular}

Mean values were significantly different from the postabsorptive values: ${ }^{*} P<0.05,{ }^{* *} P<0.01$.

$\dagger$ Values expressed as $\mu \mathrm{mol} / \mathrm{kg}$ body-wt per $\mathrm{h}$.

\$ Rate of uptake from plasma into whole-body proteins.

$\S$ Rate of entry into plasma from whole-body protein breakdown.

Table 3. Alanine flux ( $\mu \mathrm{mol} / \mathrm{kg}$ body-weight per $\mathrm{h}$ ) as determined with $\left[3,3,3-{ }^{2} \mathrm{H}_{3}\right]$ alanine and measurement of arterialized plasma in the postabsorptive and fed states

\begin{tabular}{cccccc}
\hline \hline \multirow{2}{*}{$\begin{array}{c}\text { Subject } \\
\text { no. }\end{array}$} & \multicolumn{2}{c}{ Postabsorptive state } & & \multicolumn{2}{c}{ Fed state } \\
\cline { 3 - 3 } \cline { 5 - 6 }$n n n$ & Flux & & Intake & Flux \\
\hline 01 & 371 & & 81 & 1216 \\
02 & 514 & & 83 & 729 \\
03 & 412 & & 77 & 904 \\
04 & 310 & & 79 & 1129 \\
Mean & 402 & & 80 & $994^{*}$ \\
SE & 43 & & 1 & 110 \\
\hline
\end{tabular}

* Significantly different from postabsorptive value $(P<0.05)$.

$77 \%$ higher than in the postabsorptive state (Table 2). The calculated rate of entry of leucine into the plasma compartment from endogenous sources decreased by $65 \%(P<0.01)$ while outflow of leucine for protein synthesis increased by $27 \%(P<0.05)$. Plasma alanine flux more than doubled in response to meal eating (Table 3).

Table 4 shows the effect of different plasma sampling sites on fluxes calculated with the two labelled amino acids. Leucine flux was only slightly and insignificantly lower when based on an analysis of arterialized plasma as compared with antecubital venous blood. However, alanine flux was approximately $25 \%$ lower $(P<0.05)$ when based on analysis of arterialized plasma for the postabsorptive state. There was a tendency for the difference between arterialized and venous blood to be greater during the period of meal eating.

In previous work from our laboratories, we observed that ingestion of small meals decreased the influx of leucine into plasma from endogenous sources, but no consistent increase in the rate of leucine taken up for protein synthesis was observed (Motil et al. 1981 a, b). In contrast, Rennie et al. (1982) observed a major increase in the rate of leucine incorporation into protein, but no significant change in plasma leucine influx in response to small meals. In these studies the postabsorptive and fed conditions were investigated on separate occasions (Rennie et al. 1982) or in different individuals (Motil et al. 1981a,b). Using a different experimental design, Clugston \& Garlick (1982) reported both an increased rate of leucine incorporation into body proteins and a decreased rate of leucine release with ingestion of meals in healthy lean and obese adult subjects. In their studies, a continuous 
Table 4. Comparison of leucine and alanine fluxes ( $\mu$ mol $/ \mathrm{kg}$ body-weight per $h$ ) as determined from analysis of arterialized and antecubital venous plasma

(Mean values with their standard errors)

\begin{tabular}{|c|c|c|c|c|c|c|c|c|}
\hline \multirow[b]{3}{*}{ Sample site } & \multicolumn{4}{|c|}{ Postabsorptive state } & \multicolumn{4}{|c|}{ Fed state } \\
\hline & \multicolumn{2}{|c|}{ Leucine } & \multicolumn{2}{|c|}{ Alanine } & \multicolumn{2}{|c|}{ Leucine } & \multicolumn{2}{|c|}{ Alanine } \\
\hline & Mean & $\mathbf{S E}$ & Mean & SE & Mean & $\mathbf{S E}$ & Mean & $\mathbf{S E}$ \\
\hline Antecubital vein (AV) & $85 \cdot 8$ & 4 & 509 & 55 & $116 \cdot 5$ & 5 & 1469 & 274 \\
\hline Heated hand vein (HV) & $82 \cdot 4$ & 2 & 402 & 43 & $110 \cdot 9$ & 4 & 994 & 110 \\
\hline AV:HV & 1.04 & & $1 \cdot 27$ & & $1 \cdot 05$ & & 1.4 & \\
\hline
\end{tabular}

unprimed infusion of $\mathrm{L}-\left[{ }^{14} \mathrm{C}\right]$ leucine was administered over a $12 \mathrm{~h}$ period during which small hourly meals were given, and the tracer infusion continued while the subjects were fasting for the remaining $12 \mathrm{~h}$ period at night. When feeding ceased, there were marked and almost immediate changes in plasma and expired air radioactivity, and new plateau values for specific radioactivity in the plasma leucine and expired air compartments were established within approximately $6 \mathrm{~h}$. In the present study, in which the order of fasting and feeding was the reverse, new plateau values in the fed state were also rapidly established. Thus, the present results are in general agreement with those of Clugston \& Garlick (1982); i.e. a generous intake of protein together with energy sources is associated with a prompt increase in leucine oxidation and appears to bring about an acute increase in body protein synthesis and an inhibition of protein breakdown. The earlier contradictory findings (Motil et al. $1981 a, b$; Rennie et al. 1982), with regard to the effects of meals on body protein synthesis and breakdown, may have been due, at least in part, to the comparison of postabsorptive and fed state infusions carried out on separate occasions or in different individuals. Variation between the means in the separate groups could have been sufficient to obscure differences in protein synthesis or breakdown now revealed using the paired design of the present study.

It is known that peripheral plasma concentrations of the essential amino acids are only modestly perturbed during protein meals, despite the large intake of amino acids in relation to their pool size (Munro, 1970; Wahren et al. 1976). Our findings suggest that the stability of the amino acid pool during meals is achieved by an increase in protein synthesis, an inhibition of the release of endogenous amino acids into the free amino acid pool by means of a reduction in the rate of protein breakdown, and by an increased rate of amino acid oxidation. The latter process may represent an overflow mechanism, as the activity of the amino acid degradative enzymes is proportional to substrate concentration under physiological conditions (Krebs, 1972). Thus, increased protein synthesis and decreased breakdown during meals could divert amino acids from oxidation by limiting increases in the size of the free amino acid pool.

Such a scheme was earlier proposed by Munro $(1964,1970)$, who termed the increased protein stores associated with protein meals 'labile protein', the latter accumulating or diminishing in response to the amount of protein in the diet. According to this scheme, the fraction of the amino acid intake oxidized or, alternatively, deposited in protein is determined both by the composition of a given meal and by the dietary intake during the preceding days. Hence, this may explain why $48 \%$ of the dietary leucine intake was oxidized in the lean subjects of Clugston \& Garlick (1982), compared with a value of $24 \%$ for the present study. Furthermore, protein breakdown was inhibited by only $25 \%$ during meal intake in their subjects, as compared with $65 \%$ for the present experiment. With less 
inhibition of protein breakdown, more amino acids would be susceptible to oxidation during meal eating, and body protein balance would be more negative. Indeed, the measured $\mathrm{N}$ balance was found to be negative in the study of Clugston \& Garlick (1982).

In addition to the factors of study design, and of the immediate and recent dietary history in accounting for different conclusions in postabsorptive and fed state comparisons, imperfections in the kinetic model adopted in all the studies must be acknowledged. This model assumes a single, homogeneous, free amino acid pool into which leucine is released via proteolysis. This is an oversimplification. If ingested leucine is metabolized in the splanchnic tissues before reaching the sampling pool of labelled leucine in the peripheral plasma, the estimate of leucine plasma appearance due to protein breakdown will be in error. The extent to which different study designs introduce or exaggerate these various errors remains undetermined. Clearly, the different findings among the various studies emphasizes the need to explore these aspects of amino acid kinetics before firm conclusions are drawn with regard to meal-related changes on body-protein turnover.

In the present study, leucine flux changed modestly on meal consumption, but plasma alanine flux more than doubled (Table 3). Assuming that plasma leucine kinetics reasonably indicate the pattern of whole-body protein metabolism (Waterlow et al. 1978), the great increase in plasma alanine flux must largely be due to de novo synthesis, presumably stimulated by the carbohydrate content of the meal and not due to alanine released from protein or that arising directly from the meals. In support of this, Wahren and co-workers (Wahren et al. 1976), in their studies of arterio-venous differences across the human leg, found basal alanine output to be diminished on ingestion of a carbohydrate-free meal supplying $3 \mathrm{~g}$ boiled beef $/ \mathrm{kg}$ BW. Moreover, our previous studies show that both intravenous administration of glucose and the chronic feeding of low-protein-highcarbohydrate diets result in an increased plasma alanine-N flux (Young \& Bier, 1981; Robert et al. 1982).

The present results confirm that the choice of plasma sampling site is important in determining alanine flux (Abumrad et al. 1981). The estimate of leucine flux was only insignificantly greater when determined from peripheral venous blood than from arterialized plasma (see also Pell et al. 1983). However, the estimate of alanine flux was approximately $25 \%$ greater in venous than in arterialized plasma in the postabsorptive state, when we used the deuterated tracer (Table 4). Amino acid kinetic values based on arterial blood are generally preferred to values obtained on peripheral venous blood. Although the latter is easily obtainable in man, measurements on such samples reflect metabolism in the particular organ drained and thus may yield a distorted picture of total body kinetics (McGuire et al. 1976). The present results are explained by the local efflux of unlabelled metabolites from the forearm tissues just before antecubital venous sampling, an effect that is marked for alanine because its rate of peripheral tissue efflux is great (Wahren et al. 1976). Although our findings are limited, they also suggest that this effect may be enhanced for alanine during meals because of an increase in alanine efflux from the periphery at that time.

Using [ $\left.{ }^{15} \mathrm{~N}\right] \mathrm{alanine}$ as tracer, we have found the difference between arterialized and antecubital plasma was approximately $20 \%$ (unpublished results). Other preliminary findings indicate that the fluxes measured with $\left[3,3,3-{ }^{2} \mathrm{H}_{3}\right]$ alanine are substantially greater than when simultaneously measured with $\left[{ }^{15} \mathrm{~N}\right]$ alanine or with ${ }^{13} \mathrm{C}$-labelled alanine (Young et al. 1983), presumably because of enzymically catalyzed proton exchange on the $\beta$-C (Cooper, 1976). However, we have found (unpublished results) a degree of correlation between the fluxes using ${ }^{15} \mathrm{~N}$ and deuterated alanine tracers $(>0.9)$, indicating that comparative measurements between two states, in a given individual, are probably equally as valid with one tracer as with the other. Nevertheless, it would be inappropriate to infer absolute rates of alanine turnover when the deuterated tracer is used, even when obtained from enrichments in arterialized plasma. 
This investigation was supported by NIH Grant AM 15856 and, in part, by AM 26439, AM 25995, GM 24401, GM 21700 and RR 88. L. J. Hoffer is a Fellow of the Medical Research Council of Canada.

\section{REFERENCES}

Abumrad, N. N., Rabin, D., Diamond, M. P. \& Lacy, W. W. (1981). Metabolism 30, 936-940.

Clugston, G. A. \& Garlick, P. J. (1982). Human Nutrition: Clinical Nutrition 36 C, 57-70.

Cooper, A. J. L. (1976). Journal of Biological Chemistry 251, $1088-1096$.

FAO (1970). FAO Nutritional Studies, no. 24. Rome: Food and Agriculture Organization.

Garlick, P. J., Clugston, G. A., Swick, R. W. \& Waterlow, J. C. (1980). American Journal of Clinical Nutrition 33, 1983-1986.

Krebs, H. A. (1972). Advances in Enzyme Regulation 10, 397-420.

McGuire, E. A. H., Helderman, J. H., Tobin, H. D., Andres, R. \& Berman, M. (1976). Journal of Applied Physiology 41, 565-573.

Matthews, D. E., Ben-Galim, E. \& Bier, D. M. (1979). Analytical Chemistry 51, 80-84.

Matthews, D. E., Motil, K. J., Rohrbaugh, D. K., Burke, J. F., Young, V. R. \& Bier, D. M. (1980). American Journal of Physiology 238, E473-E479.

Motil, K. J., Bier, D. M., Matthews, D. E., Burke, J. F. \& Young, V. R. (1981 a). Metabolism 30, $783-791$.

Motil, K. J., Matthews, D. E., Bier, D. M., Burke, J. F., Munro, H. N. \& Young, V. R. (1981 b). American Journal of Physiology 240, E712-E721.

Munro, H. N. (1964). In Mammalian Protein Metabolism, vol. 1, pp. 381-481 [H. N. Munro and J. B. Allison, editors]. New York: Academic Press.

Munro, H. N. (editor) (1970). In Mammalian Protein Metabolism, vol. 4, pp. 299-386. New York: Academic Press.

Pell, J. M., Caldarone, E. M. \& Bergman, E. N. (1983). Biochemical Journal 214, 1015-1018.

Rennie, M. J., Edwards, R. H. T., Halliday, D., Matthews, D. E., Wolman, S. L. \& Millward, D. J. (1982). Clinical Science 63, 519-523.

Robert, J. J., Bier, D. M., Zhao, X. H., Matthews, D. E. \& Young, V. R. (1982). Metabolism 31, $1212-1218$.

Wahren, J., Felig, P. \& Hagenfeldt, L. (1976). Journal of Clinical Investigation 57, 987-999.

Waterlow, J. C., Garlick, P. J. \& Millward, J. C. (1978). Protein Turnover in Mammalian Tissues and in the Whole Body. New York: North-Holland.

Young, V. R. \& Bier, D. M. (1981). Proceedings of the Nutrition Society 40, 343-359.

Young, V. R., Munro, H. N., Matthews, D. E. \& Bier, D. M. (1983). In New Aspects of Clinical Nutrition, pp. 43-73 [G. Kleinberger and E. Deutsch, editors]. Basel: Karger. 